\title{
Macrothink
}

\section{Errors in Second/Foreign Language Learning and Their Interpretations}

\author{
Julia Falla Wood \\ School of Education, Burman University \\ 6730 University Drive, Lacombe, Alberta, T4L 2E5, Canada \\ Tel: 1-403-782-3381 x $4100 \quad$ E-mail: juliawood@burmanu.ca
}

Received: November 3, 2016 Accepted: January 3, 2017 Published: January 8, 2017

doi:10.5296/elr.v3i1.10251 URL: http://dx.doi.org/10.5296/elr.v3i1.10251

\begin{abstract}
The aim of this article is to try to understand why the results of studies on errors in second language learning undertaken for several decades are diverse or even divergent. Some of these studies state that the mother tongue (L1) plays an important role in the learning process not only at the beginning, but also at higher levels of competency while others deny the influence of the mother tongue. The results of 60 studies on errors over a period of 40 years were contrasted to find out if a link existed between the theoretical foundations, and the interpretation of data, and conclusions of those studies. The results of the meta-analysis of studies whose theoretical foundations were related to operational cognitive strategies showed a continuum from partial to an important role of L1, and those related to order of acquisition, universal sequences showed a non-influence of L1. Another possible cause for this discrepancy was found in the method used to classify the errors. Finally, a possible cause could have been the methodological difficulties concerning the reliability and validity of the data. Only one third of the studies applied the control of bias and the triangulation of data.
\end{abstract}

Keywords: Errors in second language learning, Second language acquisition, Role of the mother tongue in second language learning/acquisition

\section{Introduction}

Teachers and students of a Second/Foreign Language (L2) have observed and experienced respectively the influence of the mother tongue (L1). Is this influence important or negligible? The question of the influence or non-influence exerted by the L1 in learning a second/foreign language (LL2) has been abundantly studied through errors. The interpretation of these errors has given birth to concepts like transfer (positive, negative), interlanguage, learning strategies and different theories, approaches or models. However, the results of these studies undertaken 
for more than six decades are diverse or even divergent. How could we reconcile the fact that the same data, namely, errors, could result in different interpretations? Could the foundational theories underlying those studies be the answer? Could the methodology used to classify the errors be a possible cause for this discrepancy? Could the reliability and validity of the data be part of this divergence?

\section{Literature Review}

This paper begins with a brief history of approaches and studies undertaken in LL2, and explains different concepts used to determine the influence of the mother tongue in the learning process. Errors made by the learners at different linguistic levels and at different learning levels that have permitted researchers to elaborate theories and models of the second language learning process will be considered. The analysis of results of these studies on errors made by L2 learners will be presented and conclusions will be drawn from these meta-analyses.

It is important to mention that the designation of Second Language is mainly used in North America. In Europe, it is more common to use the term Foreign Language, though we acknowledge there is a difference between the two terms, for the sake of this study they will be used interchangeably and referred to as L2. Bouton (1976) states that a second language is determined by the socio-linguistic environment; two different languages are spoken in the country. For example, in Canada, these are English and French. Giaccobbe (1992) states that the designation of Foreign Language is used when the languages are not spoken in the country where they are learned. As the phenomenon studied here has been observed in both cases, L2 will be used indistinctively for the purpose of this article.

The analysis of errors in LL2 are more related to linguistic aspects of the language, yet it is important to consider the learning process through concepts that fall under psychological and linguistic theories.

The LL2 is a complex phenomenon mainly studied under two psychological theories: behavioural and cognitive. This process has also been studied following a linguistic approach (Chomsky, 1965), even though, the foundations have been considered cognitivist (Chastain, 1976). Chastain states: "Chomsky adopts a rationalistic view of learning and language closely related to the basic principles and beliefs of cognitive psychology" (p. 19). Chomsky's thoughts will be presented later in the article.

According to the behaviourist learning theory of language, language learning is a habit formation, and the errors are due to habits already formed in L1. These behaviours interfere in the process of forming habits in L2. Teachers were asked to thwart persistent habits coming from L1. Conversely, the cognitivist model states that all learning activity is an integration of new knowledge. The interpretation of information is accomplished by different mental operations; and then, it is kept in our memory. Prior knowledge intervenes in the interpretation and construction of new knowledge.

Furthermore, in the cognitive approach, two positions coexisted. The first one was related to Chomsky $(1965,1976,1980,1980 b)$ and Lenneberg (1967) who claimed that there existed a 
specific language acquisition faculty, a genetic device independent of other general cognitive mechanisms. The second one, advocated by Piaget (Piatelli-Palamrini, 1979), Anderson (1983, 1985), Bruner (1975), and Slobin (1973), postulated that the general cognitive mechanisms are used for all cognitive activities, including language acquisition. Chomsky's position will now be further explored.

In Chomsky's terms, the innate knowledge we have consists of principles underlying the systems (properties applied to all languages), and what we learn, are the values of the parameters (properties applied to specific languages). It is important to note that Chomsky, himself, has not applied his theory to LL2. For certain researchers, the principles of the Universal Grammar (UG) intervene in LL2. Hence, the crucial point would be to understand the extent to which adults have access to principles and parameters of the UG.

In Chomsky's most recent work on UG (1995, 2000, 2002), called the Minimalist Program, he suggested that the language faculty consisted of a computational procedure and a lexicon. The parameters would not be linked to principles, but contained within the lexicon.

In consideration of this observation three hypotheses coexist:

1). Non-accessibility to UG: Clahsen (1990) postulated that the principles and parameters active in L1 were no longer available in learning L2, but universal cognitive strategies accomplished that role. Alternatively, Bley-Vroman, Felix \& Ioup (1988) who, after undertaking a study with 92 Korean students having a good competence in L2, stated that it was difficult to believe that students had access to UG. Meisel (1997), however, claimed that one of the most fundamental principles of UG (structure-dependency) is not available to L2 learners any more. Finally, Sauter (2002) through a study on Spanish/Italian [+ null subject] claimed that the results did not provide full evidence for total accessibility to UG, and he preferred the notion of non-accessibility.

2). Partial accessibility to UG: The results of studies undertaken by White $(1985,1986)$ showed that the learners used the parameters of L1 at the beginning, but as their competence increased in L2, they used the parameters of L2. The access to UG was actually done through L1. A study undertaken by Liceras (1988b) showed that adults had access to different parameters, but they preferred L1 parameters when they begin LL2. Schachter (1989) considered that adults could eventually have access to the absolute universals; those that are the same for all languages, and to the parameters whose values have been established by L1. Hawkins (2001) argued that the learners transfer the functional features of L1 to L2.

3). Total accessibility to UG: Flynn $(1984,1987)$ claimed that adult L2 learners had access to the same innate device that L1 learners have; therefore, the acquisition problems were the same in L1 and L2. Epstein, Flynn and Martohardjono (1996) maintained that the adult learner of L2 had access to principles and parameters of UG, and that he could assign a different value than the one assigned in L1. The debate is still open. Hence, the results of studies undertaken on non-accessibility, partial accessibility or total accessibility to UG are inconclusive.

A number of new concepts were developed in the 1980s: meta-linguistics in LL2 (Higgs \& 
Clifford, 1982), and the dichotomy between Second Language Learning and Second Language Acquisition (Krashen 1981). Learning a L2 is a conscious process leading to learning rules and structures. Acquisition, on the other hand, is considered an unconscious process leading to fluency.

As presented above, the UG-based researchers put emphasis on the language dimension of LL2. The L2 researchers mentioned below put more emphasis in the learning component of LL2. These researchers belong to two different approaches: processing approaches, and emergentist or constructionist approaches. The processing approaches examine how L2 learners process linguistic information, and consider the possibility of an innate device for language acquisition. The emergentist or constructionist approaches consider language learning guided by communicative needs, and disprove an innate, language specific, acquisition device. For the purpose of this paper, these approaches will not be considered as they are more related to the functional and pragmatic perspectives on L2 than to the linguistic perspective.

The processing approaches study how short-term memory (declarative knowledge) and long-term memory (procedural knowledge) deal with LL2. Shiffrin and Schneider (1977) claimed that the way we process information is controlled and requires attention (from the learner) or is automatic (does not require attention from the learner). McLaughlin (1987) applied Shiffrin and Schneider's concept, and stated that the L2 is learned like any other complex cognitive skill which begins with controlled processes and ends with automatic processes. Another model which has also been applied to LL2 is Anderson's Active Control of Thought Model $(1983,1985)$. This model is similar to McLaughlin, but differs in the terminology. Anderson claimed three kinds of memory instead of two: a working memory (short-term memory in McLaughlin), a declarative long-term memory and a procedural long-term memory (there is only the procedural long-term memory in McLaughlin). Later on, O'Malley and Chamot (1990) tried to insert the learning strategies into Anderson's ACT model. According to them, L2 learners would benefit from being taught learning strategies.

Second Language Learning (or Second Language Acquisition) has been understood differently depending on the underlying theory. For the behaviourists, it is conceived of in terms of conditioning and automatisms; for the cognitivists, it is viewed in terms of processes, strategies and cognitive operations; for the linguists, it is understood in terms of rules, principles and/or linguistic universals. It is, therefore, important now to consider the nature and causes of errors in learning a second language

\subsection{Errors in Learning a Second/Foreign Language}

The nature and causes of errors made by learners of L2 have been extensively studied in applied linguistics. Certain linguists (Corder, 1967; Landriault, 1980; Perdue, 1980) used the term error, while others (Rojas, 1971; Lamy, 1983) used mistake. Corder (1967) made a distinction between errors and mistakes. He considered that a mistake is related to physical conditions (fatigue) or to psychological conditions (strong emotions), and an error is the result of a transitory competency in L2. Corder (1971a, 1983b, 1986) distinguished three types of errors: 
1). Pre-Systematic (the learner does not know the rule in L2);

2). Systematic (the learner discovers the rule in L2, but he does not apply it properly);

3). Post-Systematic (the learner knows the rule, but for lack of attention or memory, he does not use it).

Carrió-Pastor (2014) in her study of lexical errors produced in scientific texts written in English by non-native researchers presents another category of errors: conceptual interference. These errors are caused by an "erroneous conception of the relationship between the image, concept and term" (p. 99). She explains that these errors are the result of a misinterpretation of concepts in L2; therefore, "The process followed to translate a concept from the mother tongue into the target language is not always followed correctly by speakers of a second language and so conceptual errors may be detected" (p. 102).

A considerable number of studies have been undertaken in order to identify the source of these errors. The following studies are examples that illustrate the influence of L1 in the learning process of L2. Some studies show that the linguistic interference or negative transfer, and the positive transfer phenomena are important in LL2; others, however, present these phenomena as negligible in LL2.

Meriö (1978) analysed 10,000 errors made by Finnish and Swedish speakers having higher knowledge of both languages, and he developed the theory of the distant interference, direct and indirect. In direct interference, errors could be attributed directly to L1; in indirect interference, errors could also be attributed to L1 through borrowed-translations. Moreover, the interference at distance could be attributed to L1through categories that do not exist in L1.

The results of Arabski's study (1979) showed that more than half of the 4,263 errors, committed by 169 Polish students learning English L2 at three levels -beginners, intermediate and advanced- can be attributed to L1.

El-Sayed (1982) studied the frequent syntactic errors committed in compositions written by Saudi students. The major source of errors was found in verbs. His findings showed that mother tongue interference was the main reason for the students' errors.

Köhlmyr (2003) analyzed 400 written compositions from the Swedish national tests in English administered in 1992 and 1995 to 16-year-old Swedish students. The results of her research indicated that the transfer of grammatical structures and rules from Swedish explained many of the errors. Also, Miliander (2003) examined university-level students of English in their second and third year of their English studies whose purpose was to become English teachers. The students received identical assignments for oral and written production. The results of this study showed an important number of errors coming from their mother tongue, Swedish. Zhengdao Ye (2004) also expressed his experience stating, "The struggle between English and Chinese is constant. When speaking English, I may think in English, but only partially; the next moment it flicks back to Chinese" (p. 138). Further, Rosén (2008) studied 400 written compositions collected between 1999 and 2005). She analyzed the written production of Swedish students learning German at different levels: beginners, 
intermediate and advanced learners. The results demonstrated that even though the texts produced by the Swedish students were grammatically correct, the text was considered by German assessors to be "un-German". The Swedish students structured and sequenced information differently from native Germans. She concluded that this is another kind of transfer to be considered.

Qiyun Zhang (2010) investigated the tag question errors in Chinese people, and stated: "Many elements of the native language have no corresponding counterparts in the target language; L1 habits would cause errors in the L2, and learners would transfer inappropriate properties of L1. This is true for English tag question learning" (p. 579). Pavlenko (2011) stated: "The enormous literature on transfer or cross-linguistic influence from L1 indicates that even advanced L2 speakers continue to be influenced by their L1 in a range of domains." (p. 146)

Carrió-Pastor (2012) investigated the lexical errors committed by Spanish researchers writing scientific texts. The results showed that more than half of the errors (negative and positive transfer) came from the influence of L1. Tüm (2012) analysed the errors committed by Russian learners learning Turkish L2. When Russian and Turkish are compared, in term of similarity and dissimilarities, various aspects of the language differ: alphabetic system, synthetic vs. agglutinative, article, adjective, verb, and word order. The results confirmed interference from the mother language (assumption that L2 and L1 are similar), an incomplete knowledge of L2 (transferring this knowledge in a sentence in L2), and the complexity of the L2 (not being aware of the fact that L2 has more suffixes than L1).

Mourssi (2013) declared: "Arab learners of English think in Arabic first, before performing the task in English. [...] This happens with most of the Arab learners of English up to higher levels" (p. 255).

Finally, Lixin Xia (2015), in her research on error analysis of the word class of Chinese college students, stated: "Interlingual transfer might account for most of the errors. As there are substantial differences between Chinese and English in regard to the word class, Chinese learners may inappropriately apply their mother tongue rules and knowledge to their English learning” (p. 44).

All these studies from different L1's (Arabic, Chinese, English, Finnish, French, Polish, Russian, Spanish, and Swedish) learning L2's (English, Finnish, German, Swedish, and Turkish), seem to converge in their results, that is, that the influence of L1 in learning L2 is substantial. However, in LL2, what is the role attributed to the transfer phenomenon? There are two positions:

1). Those who consider that the influence of L1 is very important, even at higher levels of competence in L2; and 2. Those who minimize the influence exerted by L1, and emphasize the contribution of universal principles.

In contrast, Dulay and Burt (1974d) determined that only 3\% of the errors were due to interference of L1. According to these researchers, the errors did not originate in the influence of L1, but were the result of an imperfect knowledge of L2. They illustrated that language 
acquisition follows a universal order. For example, different learners with different L1 will have the same difficulties in LL2. Meisel, Clahsen and Pienemann (1981) found that the transfer in LL2 is negligible. Krashen (1983) considered that the transfer phenomenon was only due to ignorance, and did not play an important role in LL2. Felix (1980a) analyzed three syntactic structures of Anglophone children learning German L2 and concluded that transfer was not an important strategy in LL2. Zobl (1984) has observed that the acquisition of determinants "a" and "the" in English are easier for those learners whose language makes the distinction between definite and indefinite determinants (French and Spanish) than for those learners whose language does not make that distinction (Chinese and Russian).

White (1986) has also compared Spanish and French students learning English as L2, and observed that the French students learn the subject-pronouns faster than the Spanish students, and that it is probably because Spanish allows the null-subject while English and French do not.

Towel \& Hawkins (1994) determined that transfer affected all linguistic levels. They considered that people were more aware of the transfer when L1 and L2 differed on a particular structure; in that case, the learner would use a structure that does not belong to L2. At the phonetic level, an English student learning French L2 would have the tendency to pronounce the word "fin," like "fan", or a French student learning English L2 would say "zees," for the English word "this." Furthermore, they would transfer the phonological properties from English to French in the first case and from French to English in the second one. Clahsen and Muysken (1986), in their study of word order, sustained that the transfer existed, but it could be better understood as a discursive strategy.

The transfer phenomenon has been examined for more than six decades. Not only have the linguistic factors, at different linguistic levels, been studied, but also the psycho-socio-affective factors. Some researchers see it as an unconscious learning strategy, others as a cognitive conscious strategy. Certain scientists consider it to be an important phenomenon in the learning process; others minimalize its intervention in LL2. Some experts believe that it is important at the beginning of the learning process, but it disappears as the competence increases. Others maintain that it continues to intervene, and it does not disappear, even in highly competent bilinguals.

Another important concept related to LL2 and used to explain the errors made by the learners is interlanguage (IL). This concept will now be explained.

\subsection{Interlanguage}

It is Selinker (1972) who used this term for the first time. He also realized that the structures utilized by learners of L2 were not the same as the ones a person would use in his/her mother tongue to express the same meaning. Interestingly, numerous studies have been undertaken to define those processes and strategies, but none of them have questioned the concept of interlanguage itself except Adjémian (1976), who pointed out that the ILs were natural languages and subject to the same linguistic rules that could create new structures.

Others have presented the concepts of variability in IL (Othman, 2003) who claimed that "for 
the past three decades, there has been a growing number of empirical and theoretical works dealing with variation in interlanguage" (p. 81). Ellis (2004) declared that variability in IL depended on the nature of the task. Al-khresheh's review (2015) of Interlanguage Theory revealed that the IL theory was almost no longer valid in the field of second language acquisition for the reasons presented by Adjémian (1976).

In this literature review, the analyses of errors showed two main positions: Researchers who claim mother-tongue influence, from beginners to advanced learners; and those who claim a minimal or even a non-influence from the mother tongue.

However, what implications could this influence or non-influence have in life? First, it may help to have a better understanding of the learning process and, why not, another possible theory or model. Second, it may have implications at a pedagogical level, in particular, in Canada where the immigrant population in schools and universities has become more and more important, due to world conflicts and to economic difficulties, in particular, in developing and underdeveloped world countries.

\section{Meta-Analysis of Studies on Errors}

In a previous study, Falla (2000) analyzed 60 studies of errors in LL2 over a period of 40 years. The purpose of the analysis was to find out if links existed between the theoretical foundations, the interpretation of data, and the conclusions of those studies. These studies were selected according to the following criteria: errors committed by L2 learners, the relationship between errors in L1/L2, and errors and internal processes present in LL2. These were chosen from three different databases: ERIC, Dissertation Abstracts, and Psychological Abstracts. They were analyzed through two analytical grids. The first analytical grid was used to determine the research design, the objective, the theoretical foundations, the sampling, the collection of data, the type of data, the linguistic level (lexical, morphological, phonological, semantic, and syntactic), and the learning level (beginner, intermediate, advanced), and the results. The second analytical grid was used to analyze the conditions in which the collection of data was carried out, in order to evaluate the reliability and validity of the data.

All of the studies examined here were descriptive. The sampling was composed of subjects accessible to the researcher. These subjects were in a guided LL2 or in a non-guided LL2. The age of the subjects was divided into four categories: children (4-12), adolescents (13-17), young adults (18-30), and adults (31-69). The highest number of studies was found in the category of young adults. The data collection mainly consisted of translation exercises, interviews (free expression with and without pictures), and repetition exercises. Some studies did not mention the number of errors analyzed. Among those that did mention them, the number varied between 80 and 29,980. The linguistic levels were: morphological-syntactic, followed by syntactic, and lexical-morphological-syntactic. The L1 of most of the studies was Spanish, followed by French, then Japanese, and, finally, Chinese. English was the L2 most studied, followed by French, German, and Spanish, respectively. Most of the studies were completed at three levels: beginners, intermediate, and advanced. 


\section{Interpretation of data}

With respect to the triangulation of data, more than half of the studies have used this procedure. The impact of bias, the conditions of data collection and the correction of written composition have been clearly defined. Only one third of the studies had both triangulations of data and control of bias.

The theoretical foundations were divided into two categories: 1). Those foundations that could be confirmed; and 2). Those that could not. Falla (2000) called the first category the operational cognitive foundations which concerned the different cognitive strategies. The results of the first category led us to record anywhere from a partial influence of L1 to an important influence of L1. The theoretical foundations of this second category are related to order of acquisition, universal sequences, and the innate faculty for basic linguistic structures. The results of this category show a non-influence of L1. Some of these studies accept a partial influence of L1. The results of $81 \%$ of studies show a partial or an important influence of $\mathrm{L} 1$, and the results of $19 \%$ show a non-influence of $\mathrm{L} 1$.

\section{Conclusion}

In this paper we have discussed the different concepts used to explain the errors made by learners at different linguistic levels and at different learning levels, the results of 60 studies on errors during a 40-year-period, for which the conclusions vary from a non-influence to an important influence of the mother tongue in learning a second language, and finally, the possible causes of this diversity or even the divergence of results.

As mentioned earlier, the theoretical foundations related to universal principles which could not be confirmed was one of the causes of the divergent results. Another possible cause for this discrepancy was found in the method used to classify the errors. Some questions that arose: Are these transfer errors, or developmental errors? Where is the limit? The same error could be the result of two different causes or two different interpretations? Could Errors be misclassified?

Finally, a possible cause could have been the methodological difficulties concerning the reliability and validity of the data. As mentioned before, only one third of the studies applied the control of bias and the triangulation of data.

It would be interesting to analyze the errors made by learners of the second language, taking into consideration a cognitive theoretical foundation, having a good knowledge of the mother tongue of the learner, and emphasizing the methodological considerations concerning the control of bias and the triangulation of data.

More research is needed to better understand the learning process of a L2, and to find ways to help teachers and students to cope better with the process of teaching and learning English as a Second Language in a new country and in a new education system. 


\section{Macrothink}

\section{References}

Adjémian, C. (1976). On The Nature of Interlanguage Systems. Language Learning, 26(2), 297-320. http://dx.doi.org/10.1111/j.1467-1770.1976.tb00279.x

Al-khresheh, M. H. (2015). A Review Study of Interlanguage Theory. International Journal of Applied Linguistics and English Literature IJALEL, 4(3), 123-131. http://dx.doi.org/10.7575/aiac.ijalel.v.4n.3p.123

Anderson, J. R. (1983). The architecture of cognition. Cambridge, MA: Harvard University Press.

Anderson, J. R. (1985). Cognitive psychology and its implications. New York: W.H. Freeman.

Arabski, J. (1979). Errors as indications of the development of interlanguage. Katowice: Uniwersytet Śląski.

Bley-Vroman, R. W., Felix, S. W., \& Loup, G. L. (1988). The accessibility of Universal Grammar in adult language learning. Second Language Research, 4(1), 1-32. http://dx.doi.org/10.1177/026765838800400101

Bouton, Ch. P. (1976). Le développment du language: aspects normaux et pathologiques. Paris: Les Presses de l'UNESCO et Masson.

Bruner, J. S. (1975). Language as an instrument of thought. In A. Davies (Ed.), Problems of Language and Learning. London: Heinemann.

Carrió-Pastor, M. L., (2012). A contrastive analysis of epistemic modality in Scientific English. Revista de Lenguas par fines específicos, 19, 15-132.

Chastain, K. (1976). Developing Second-Language Skills: Theory to Practice. Chicago: Rand McNally.

Carrió-Pastor, M. L., \& Mestre-Mestre, E. M. (2014). Lexical errors in second language scientific writing: Some conceptual implications. International Journal of English Studies, 14(1), 97-108. http://dx.doi.org/10.6018/ijes/14/1/154361

Chomsky, N. (1995). The Minimalist program. Cambridge, MA: The MIT Press.

Chomsky, N. (1965). Aspects of the theory of syntax. Cambridge: M.I.T. Press.

Chomsky, N. (1976). Reflections on Language. London: Temple Smith.

Chomsky, N. (1980). Rules and Representations. New York: Columbia University Press.

Chomsky, N. (1980b). On cognitive structures and their development: A reply to Piaget. In Piatelli-Palmarini (Ed.), Language and Learning. London: Routledge \& Kegan.

Chomsky, N. (2000). New horizons in the study of language and mind. Cambridge: Cambridge University Press. https://doi.org/10.1017/CBO9780511811937 


\section{Macrothink}

Education and Linguistics Research ISSN 2377-1356

Chomsky, N., Belletti, A., \& Rizzi, L. (2002). On nature and language. Cambridge: Cambridge University Press. https://doi.org/10.1017/CBO9780511613876

Clahsen, H., \& Muysken, P. (1986). The availability of universal grammar to adult and child learners - a study of the acquisition of German word order. Second Language Research, 2(2), 93-119. http://dx.doi.org/10.1177/026765838600200201

Clahsen, H. (1990). The Comparative Study of First and Second Language Development. $\begin{array}{lllll}\text { Studies in Second } & \text { Language }\end{array}$ http://dx.doi.org/10.1017/s0272263100009050

Corder, S. P. (1967). The Significance of Learner's Errors. International Review of Applied Linguistics in Language Teaching, 5(1-4), 161-9. http://dx.doi.org/0.1515/iral.1967.5.1-4.161

Corder, S. P. (1971a). Idiosyncratic Dialects and Error Analysis. International Review of

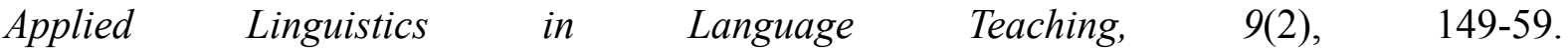
http://dx.doi.org/10.1515/iral.1971.9.2.147

Corder, S. P. (1983b). A Role for the Mother Tongue. In S. Gass, \& L. Selinker (Eds.), Language Transfer in Language Learning. Rowley, Mass: Newbury House.

Corder, S. P. (1985). Error Analysis and Interlanguage. Oxford: Oxford University Press.

Corder, S. P. (1986). The significance of learners' errors. In B. Robinett, \& J. Schachter (Eds.), Second Language Learning. Michigan: University of Michigan Press.

Dulay, H., \& Burt, M. (1974d). A New Perspective on the Creative Construction Process in Child Second Language Acquisition1. Language Learning, 24(2), 253-278. http://dx.doi.org/10.1111/j.1467-1770.1974.tb00507.x

Ellis, R. (2004). The Definition and Measurement of L2 Explicit Knowledge. Language Learning, 54(2), 227-275. https://doi.org/10.1111/j.1467-9922.2004.00255.x

El-Sayed, A. M. (1982). An investigation into the syntactic errors of Saudi freshmen's English compositions. Indiana University of Pennsylvania.

Epstein, S. D., Flynn, S., \& Martohardjono, G. (1996). Second language acquisition: Theoretical and experimental issues in contemporary research. Behavioral and Brain Sciences Behav Brain Sci, 19(04), 677-714. http://dx.doi.org/10.1017/s0140525x00043521

Falla, J. (2000). La recherche sur les erreurs en apprentissage des langues secondes et le rôle de la traduction mentale (Doctoral Dissertation). Retrieved from Bibliothèques et Archives Canada. (Accession Order No. NQ52150).

Felix, S. (1980a). Second Language Development: Trends and Issues. Tübingen: Gunter Narr. Flynn, S. (1984). A universal in L2 acquisition based on a PBD typology. In F. Eckman et al. (Eds.), Universals of Second Language Acquisition. Rowley, Mass: Newbury House.

Flynn, S. (1987). A Parameter-Setting Model of L2 Acquisition. Studies in Theoretical Psycholinguistics. http://dx.doi.org/10.1007/978-94-009-3747-5 


\section{Macrothink Institute ${ }^{\text {TM }}$}

Giacobbe, J. (1992). A cognitive view of the role of L1 in the L2 acquisition process. Second Language Research, 8(3), 232-250. http://dx.doi.org/10.1177/026765839200800304

Hawkins, R. (2001). Second Language Syntax: A Generative Introduction. Oxford: Blackwell. https://doi.org/10.1191/026765801681495868

Higgs, T.V. \& Clifford, R. (1982). The push toward communication. Curriculum Competence and the Foreign Language Teacher. Lincolnwood: National Textbook Co.

Köhlmyr, P. (2003). To Err is Human....: An investigation of grammatical errors in Swedish 16-year-old learners' written production in English. Goteborg Universitet, Goteborg.

Krashen, S. D. (1981). Second language acquisition and second language learning. Oxford: Pergamon Press.

Krashen, S. (1983). Newmark's ignorance hypothesis and current second language acquisition theory. Language Transfer in Language Learning. Rowley, Mass: Newbury House.

Lamy, A. (1983). Conceptualisation et pédagogie de la faute : cinq exemples. Le français dans le monde, 174, 60-63.

Landriault, B. (1980). Analyse des erreurs et enseignement des langues. Bulletin de l'ACLA, 2, 84-85.

Lennenberg, E. (1967). Biological Foundation of Language. New York: Wiley and Sons.

Liceras, J. (1988b). Learnability: delimiting the domain of core grammar as distinct from the marked periphery. In S. Flynn, \& W. O’Neil (Eds.), Linguistic Theory in Second Language Acquisition. Dordrecht: Kluwer.

Lixin, X. (2015). An Error Analysis of the Word Class: A Case Study of Chinese College Students. International Journal of Emerging Technologies in Learning, 10(3), 41-45. http://dx.doi.org/10.3991/ijet.v10i3.4563

Mackey, W.F. (1982). Interaction, interférence et interlangue: rapports entre bilinguisme et didactique des langues. Langues et linguistique, 8(1), 45-64.

McLaughlin, B. M. (1987). Theories of Second Language Learning. London: Edward Arnold.

Meisel, J. (1997). The acquisition of the syntax of negation in French and German: Contrasting first and second language development. Second Language Research Second Lang Res, 13(3), 227-263. http://dx.doi.org/10.1191/026765897666180760

Meisel, J., Clahsen, H., \& Pienemann, M. (1981). On determining developmental stages in natural second language acquisition. Studies in Second Language Acquisition, 3, 109-135. https://doi.org/10.1017/S0272263100004137

Meriö, K. (1978). The psycholinguistic analysis and measurement of interference errors. IRAL, 16(1), 27-44. https://doi.org/10.1515/iral.1978.16.1-4.27 


\section{Macrothink

Miliander, J. (2003). We Get the Answer We Deserve. A study of vocabulary in a spoken and written corpus of advanced learner English. Karlstad University: Karlstad University Studies.

Mourssi, A. (2013). The efficacy of error analysis on second language learners' written accuracy: an empirical study in the context of Arab learners of English. International Research Journals, 4(3), 249-256.

O’Malley, J.M. \& Chamot, A. (1990). Learning Strategies in Second Language Acquisition. Cambridge, New York: Cambridge University Press. https://doi.org/10.1017/CBO9781139524490

Othman, J. (2003). Variation in interlanguage: Theoretical perspectives and empirical evidence. In H. Abd-Rahim, \& S. Manan (Eds.), Current issues in linguistics, literature and language teaching (pp. 139-191). Malaysia, Penang: USM Press.

Pavlenko, A. (2011). Thinking and speaking in two languages. Bristol, UK: Multilingual Matters.

Perdue, C. (1980). L'analyse des erreurs : Un bilan pratique. Langages, 14(57), 87-94. http://dx.doi.org/10.3406/lgge.1980.1840

Piatelli-Palmarini, M. (1979). Théories du langage, théories de l'apprentissage: le débat entre Jean Piaget et Noam Chomsky. Paris : Seuil.

Richards, J. (ed.) (1974). Error Analysis: Perspectives on Language Acquisition. London: Longman.

Rojas, C. (1971). L'analyse des fautes. Le français dans le monde, 81, 58-63.

Rosén, C. (2008). "Warum klingt das nicht deutsch?": Probleme der Informationsstrukturierung in deutschen Texten schwedischer Schiler und Studenten. Saarbrücken: VDM-Verl. Müller.

Sauter, K. (2002). Transfer and access to universal grammar in adult second language acquisition s.n.

Schachter, J. (1989). Testing a proposed universal. In S. Gass, \& J. Schachter (Eds.), Linguistic Perspectives on Second Language Acquisition. Cambridge: Cambridge University Press.

Selinker, L. (1972). Interlanguage. International Review of Applied Linguistics, 10, 209-31. https://doi.org/10.1515/iral.1972.10.1-4.209

Shiffrin, R. M., \& Schneider, W. (1977). Controlled and automatic human information processing: II. Perceptual learning, automatic attending and a general theory. Psychological Review, 84(2), 127-190. http://dx.doi.org/10.1037/0033-295x.84.2.127

Slobin, D. I. (1973). Cognitive prerequisites for the development of grammar. In Ch. Ferguson, \& D. I. Slobin (Eds.), Studies of Child Language Development. New York: Holt, Rinehart and Winston Inc. 


\section{Macrothink}

Education and Linguistics Research

ISSN 2377-1356 2017, Vol. 3, No. 1

Towell, R., \& Hawkins, R. (1994). Approaches to second language acquisition. Cleveland: Multilingual Matters.

Tüm, G. (2012). Reasons for Errors Done by Belarusian Learners Learning Turkish as a Foreign Language. H. U. Journal of Education, 42, 418-429.

White, L. (1985). The Pro-Drop parameter in adult second language acquisition. Language Learning, 35, 47-62. https://doi.org/10.1111/j.1467-1770.1985.tb01014.x

White, L. (1986). Implications of parametric variation for adult second language acquisition: An investigation of the pro-drop parameter. In V. Cook (Ed.), Experimental Approaches to Second Language Acquisition (pp. 55-72). Oxford: Pergamon.

Ye, Z. (2004). Chinese categorization of interpersonal relationships and the cultural logic of Chinese social interaction: An indigenous perspective. Intercultural Pragmatics, 1(2), 211-230. http://dx.doi.org/10.1515/iprg.2004.1.2.211

Zhang, Q. (2010). A Study of Chinese Learning of English Tag Questions. Journal of Language Teaching and Research, 1(5), 578-582. http://dx.doi.org/10.4304/jltr.1.5.578-582

Zobl, H. (1984). Cross-language generalizations and the contrastive dimension of the interlanguage hypothesis. In A. Davis, C. Criper, \& A. Howatt (Eds.), Interlanguage. Edinburgh: Edinburgh University Press.

\section{Copyright Disclaimer}

Copyright reserved by the author(s).

This article is an open-access article distributed under the terms and conditions of the Creative Commons Attribution license (http://creativecommons.org/licenses/by/3.0/). 